Канд. техн. наук А.О. Ковальов, О.О. Нестеренко

\title{
УДОСКОНАЛЕННЯ ТЕХНОЛОГІЇ ПЕРЕРОБКИ КОНТЕЙНЕРІВ НА СТАНЦІї ЗА ДОПОМОГОЮ ПЕОМ
}

\author{
Представив д-р техн. наук, професор О.М. Огар
}

\begin{abstract}
Вступ. Основною тенденцією в розвитку вітчизняного та світового транспорту $\epsilon$ швидке зростання контейнерних перевезень, які в максимальній мірі відповідають вимогам ринкової економіки. Вони стають невід'ємною частиною товаросупровідної розподільчо-складської системи, що забезпечує безперебійну доставку різної продукції в торгову мережу, а також вантажів виробничотехнічного призначення в галузь промислового виробництва. Досягається високий позатранспортний ефект від підвищення схоронності вантажів, значно прискорюється їх доставка, підвищується конкурентоспроможність та екологічність транспортної продукції.
\end{abstract}

Але, незважаючи на це, й досі залишаються труднощі в організації контейнерних перевезень. Однією $з$ причин погіршення роботи підрозділів залізниці $\epsilon$ недосконалість технології i організації роботи контейнерних площадок у взаємодії 3 власниками вантажів.

Метою статті $\epsilon$ обгрунтування використання математичних моделей для підвищення ефективності використання вагонів на контейнерних площадках.

Виклад основного матеріалу. Контейнерні перевезення - один 3 найважливіших резервів підвищення продуктивності та зниження собівартості перевезення вантажів. Перевагами контейнерних перевезень $€$ Зниження 
витрат на тару та упаковку, підвищення продуктивності та покращення умов праці, прискорення доставки вантажів та підвищення ступеня їх збереження, підвищення якості перевізного процесу в цілому. Перевезення вантажів у контейнерах дозволяє уніфікувати транспортну технологію, що робить цей вид доставки вантажів дуже привабливим не тільки для морських ліній, але й для автотранспорту та залізниці.
Підвищення ефективності використання вантажного вагона на контейнерній площадці можливе створенням відповідних математичних моделей та дослідженнями цих моделей на програмно-електронній обчислювальній машині (ПЕОМ). Розглянемо математичну модель, коли контейнери прибувають порожні і відправляються навантажені. У спрощеному вигляді граф технології вантажної переробки контейнерів на станції наведений на рис. 1.

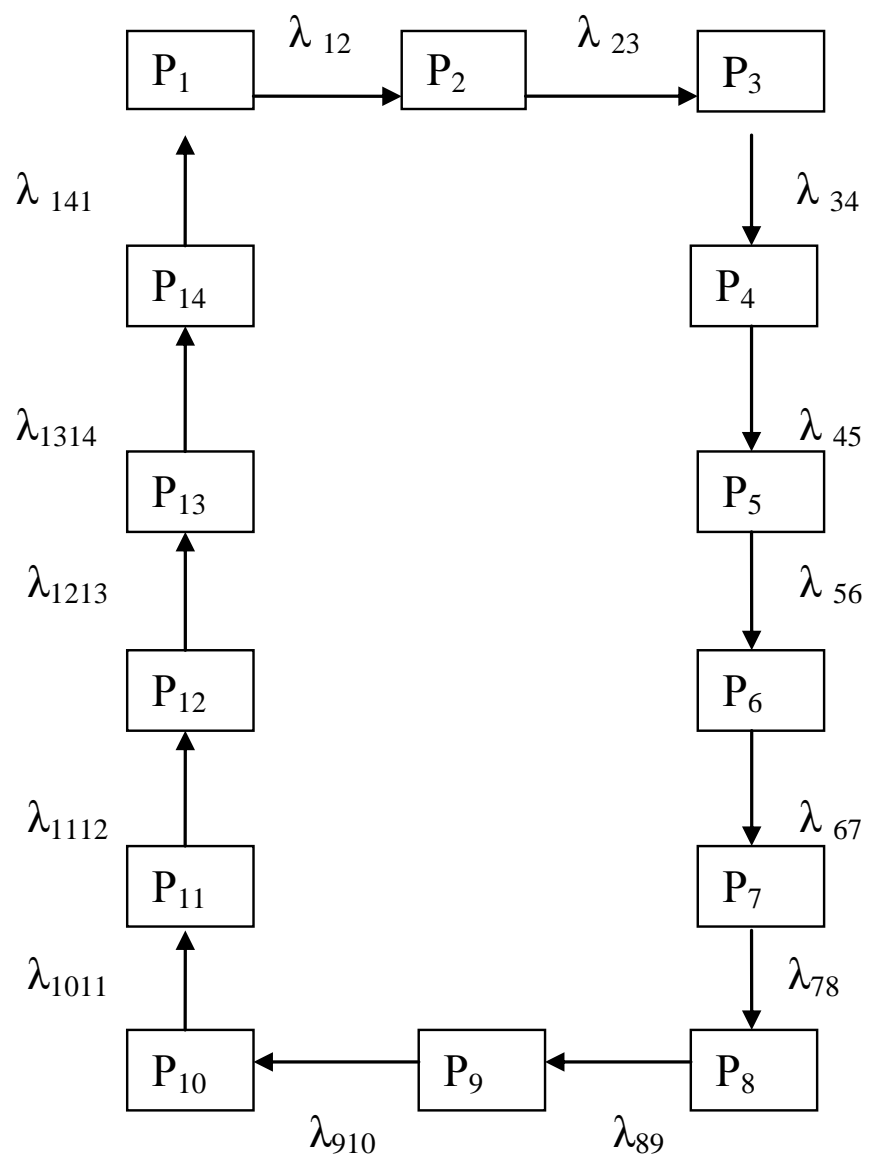

Рис. 1. Граф станів середньотоннажного контейнера на контейнерній площадці

Дана система може перебувати у таких станах:

$\mathrm{P}_{1}$ - очікування контейнера у вагоні вивантаження на площадку;

$\mathrm{P}_{2}$ - вивантаження контейнера 3 вагона на площадку або на автомобіль;

$\mathrm{P}_{3}$ - очікування контейнера вивезення до міста;

$\mathrm{P}_{4}$ - оформлення документів при навантаженні на автотранспорт;
$\mathrm{P}_{5}$ - очікування навантаження на автотранспорт;

$\mathrm{P}_{6}$ - навантаження порожнього контейнера на автотранспорт з площадки;

$\mathrm{P}_{7}$ - доставка порожнього контейнера до складу вантажоодержувача;

$\mathrm{P}_{8}$ - завантаження контейнера вантажем;

$\mathrm{P}_{9}$ - доставка порожнього контейнера на станцію; 
$\mathrm{P}_{10}$ - оформлення документів при вивантаженні контейнера;

$\mathrm{P}_{11} \quad-$ очікування контейнера вивантаження на площадку;

$\mathrm{P}_{12}$ - вивантаження контейнера на площадку або у вагон;
$\mathrm{P}_{13}$ - накопичення контейнерів на площадці на комплект до навантаження у вагон;

$\mathrm{P}_{14}$ - навантаження контейнера $\mathrm{y}$ вагон.

Нормувальна умова така

$$
\mathrm{P} 1+\mathrm{P} 2+\mathrm{P} 3+\mathrm{P} 4+\mathrm{P} 5+\mathrm{P} 6+\mathrm{P} 7+\mathrm{P} 8+\mathrm{P} 9+\mathrm{P} 10+\mathrm{P} 11+\mathrm{P} 12+\mathrm{P} 13+\mathrm{P} 14=1 \text {. }
$$

Для визначення кількості контейнерів у кожному стані системи у подальших розрахунках переходимо до середніх чисельностей контейнерів.

Диференціальні рівняння Колмогорова у такому випадку мають вигляд:

$$
\begin{aligned}
& \frac{d m_{1}}{d t}=\lambda_{1617^{m}} m_{16}-\lambda_{12} m_{1} ; \\
& \frac{d m_{2}}{d t}=\lambda_{12} m_{1}-\lambda_{23} m_{2} \text { ； } \\
& \frac{d m_{3}}{d t}=\lambda_{23} m_{2}-\lambda_{34} m_{3} \text {; } \\
& \frac{d m_{4}}{d t}=\lambda_{34} m_{3}-\lambda_{45} m_{4} \text {; } \\
& \frac{d m_{5}}{d t}=\lambda_{45} m_{4}-\lambda_{56} m_{5} \text {; } \\
& \frac{d m_{6}}{d t}=\lambda_{56} m_{5}-\lambda_{67} m_{6} \text {; } \\
& \frac{d m_{7}}{d t}=\lambda_{67} m_{6}-\lambda_{78} m_{7} \text {; } \\
& \frac{d m_{8}}{d t}=\lambda_{78} m_{7}-\lambda_{89} m_{8} \text {; } \\
& \frac{d m_{9}}{d t}=\lambda_{89} m_{8}+\lambda_{910} m_{9} ; \\
& \frac{d m_{10}}{d t}=\lambda_{910} m_{9}-\lambda_{1011} m_{10} \\
& \frac{d m_{11}}{d t}=\lambda_{1011^{m}}{ }_{10}-\lambda_{1112} m_{11} \text {; } \\
& \frac{d m_{12}}{d t}=\lambda_{1112} m_{11}-\lambda_{1213} m_{12} \text {; } \\
& \frac{d m_{13}}{d t}=\lambda_{1213} m_{12}-\lambda_{1314} m_{13} \text {; } \\
& \frac{d m_{14}}{d t}=\lambda_{1314} m_{13}-\lambda_{1415} m_{1} \text {. }
\end{aligned}
$$


Розв'язування системи рівнянь задовольняє нормувальну умову:

$$
m_{1}+m_{2}+m_{3}+m_{4}+m_{5}+m_{6}+m_{7}+m_{8}+m_{9}+m_{10}+m_{11}+m_{12}+m_{13}+m_{14}=N \quad,
$$

де $N$ - загальна чисельність контейнерів на контейнерній площадці;

$m_{i}-$ кількість контейнерів у $i$-му технологічному стані; $\lambda_{i}-$ інтенсивність переходу контейнера із стану в стан.

Проведено дослідження моделі технології обробки контейнера на станції (рис. 2).

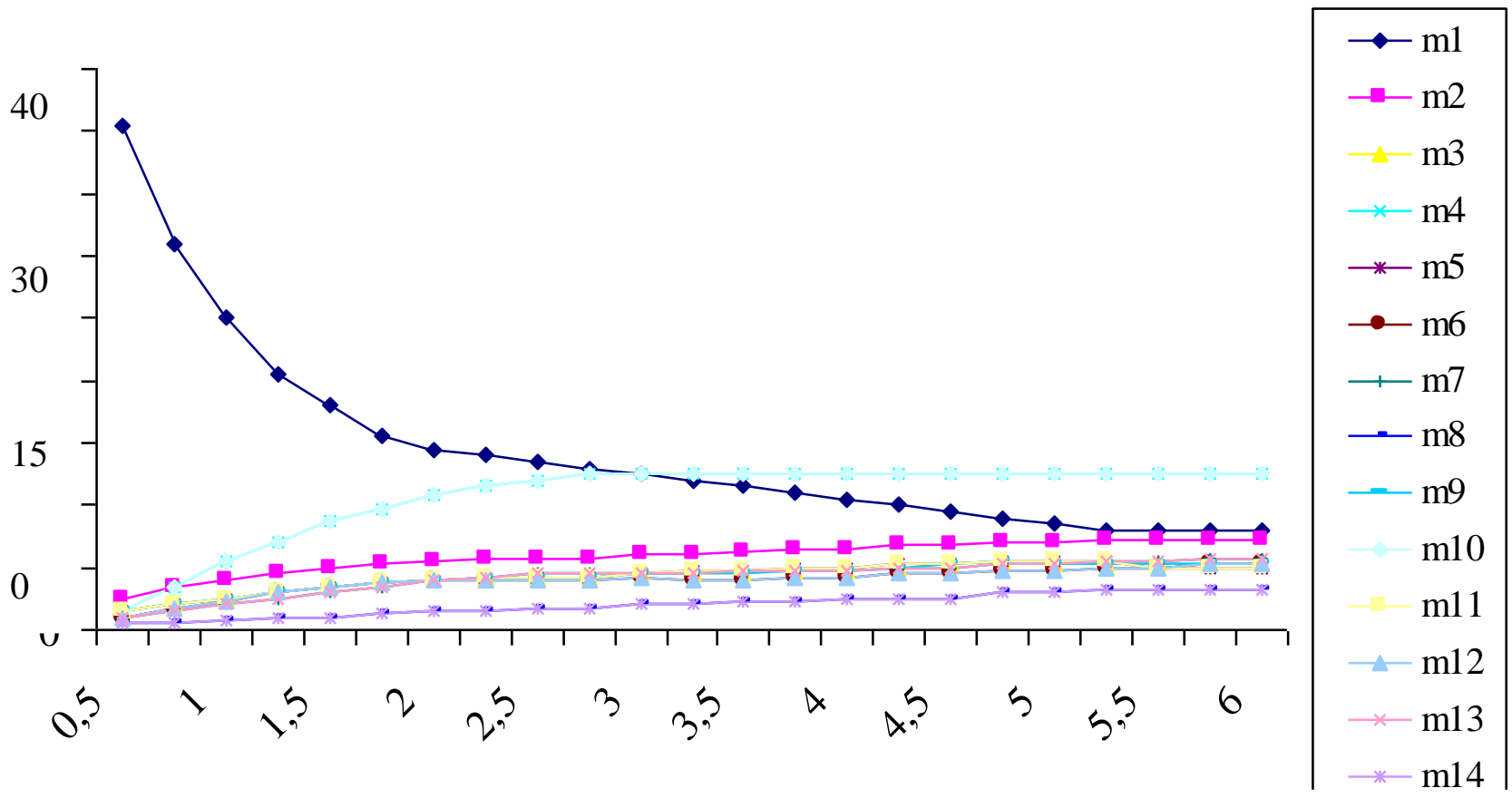

Рис. 2. Залежності середніх чисельностей контейнерів на станції

Дана модель відбиває технологію роботи середньотоннажного контейнера на контейнерній площадці, на основі якої визначається середня чисельність контейнерів під різними технологічними операціями та в їх очікуванні, що дозволяє удосконалити технологію роботи контейнерних площадок шляхом визначення їх оптимального технічного оснащення.

Висновок. Значення контейнерних перевезень у транспортному комплексі на сучасному етапі розвитку ринкових відносин досить велике. Пріоритетним цей вид перевезень вантажів на будь-якому виді транспорту $\epsilon$ завдяки скороченню суми витрат на зберігання, перевантаження, складування, оплату праці тощо та скороченню часових характеристик за згаданими видами робіт. Використання математичних моделей дає змогу удосконалити технологію роботи 3 контейнерами та вибрати оптимальне оснащення контейнерної площадки, завдяки чому зменшується вартість 
простоїв у системі обслуговування вагонів, скорочуються витрати на утримання технічних засобів системи та визволяються додаткові навантажувальні ресурси.
Підсумком такого впровадження буде прискорення обігу вантажних вагонів та в цілому підвищення економічного ефекту від перевезень.

\section{Сиисок літератури}

1. Інтермодальні перевезення. Офіційний веб-сайт Укрзалізниці [Електронний ресурс]. - Режим доступу: http://uz.gov.ua/cargo_transportation/intermodal_transportation /

2. Котенко, А.М. Математична модель операцій на контейнерних пунктах [Текст] / А.М. Котенко, В.І. Петров // Зб. наук. праць. - Харків: ХарДАЗТ, 2003. - Вип. 53. - С. 51-58.

Ключові слова: контейнерні перевезення, контейнерна площадка, математична модель, середньтоннажний контейнер.

\section{Анотації}

3 розвитком сучасних технологій актуальним $є$ використання ПОЕМ для удосконалення існуючих технологій роботи та оптимізації виробництва.

3 цією метою в статті було проведено дослідження доцільності використання математичних моделей на прикладі роботи контейнерної площадки. Підсумком стало зменшення витрат на утримання технічних засобів, скорочується час простоїв вагонів, внаслідок чого підвищується ефективність виробництва. Також складання уніфікованих математичних моделей дозволяє застосовувати їх для поліпшення технологій роботи на інших залізничних станціях.

С развитием современных технологий актуальным является использование ПЭВМ для усовершенствования существующих технологий работы и оптимизации производства.

С этой целью в статье было проведено исследование целесообразности использования математических моделей на примере работы контейнерной площадки. Итогом стало уменьшение расходов на содержание технических средств, сокращается время простоев вагонов, в результате чего повышается эффективность производства. Также составление унифицированных математических моделей позволяет применять их для улучшения технологий работы на других железнодорожных станциях.

With the development of advanced technologies relevant is the use of a PC for the improvement of existing technologies and the optimization of production.

To this end, in article was investigated whether use of mathematical models for the example of the container yard. The result was the reduction in the cost of the hardware, reducing the time of standstill, resulting in increased efficiency. Also of aligned mathematical models can be used to improve the technologies for the other railway stations. 